\title{
Response of Running Shoot tips of Strawberry (Fragaria $x$ ananasa) for in vitro Propagation in Kurdistan Region of Iraq
}

\author{
Gharbia H. Danial* , Diaa A. Ibrahim* , Mobasher S. Omer \\ Scientific Research Center, College of Science, University of Duhok, Iraq
}

\begin{abstract}
Strawberry (Fragaria $x$ ananasa) is grown for its excellent food and nutritional value in many parts of the world. The main objective of this study was to optimize an efficient, reliable and economical protocol for In vitro propagation of strawberry plants. The effect of BAP (6-Benzyl amino purine) alone or combined with (Gibberellic acid, Kinetin, IBA) and the effects of TDZ (Thidiazuron) on shoot proliferation of strawberry (Fragaria $x$ ananasa) has been evaluated. It has been noticed that $2.0 \mathrm{mgl}^{-1}$ BAP combination with $0.25 \mathrm{mgl}^{-1}$ IBA able to generate the maximum number of shoots / explants (6.375) with high shoot length $(0.675 \mathrm{~cm})$ and high leaves number /explants (19.0). On the other hand, presence of $1.5 \mathrm{mgl}^{-1}$ of TDZ in the nutrient medium increased the shoot number/explants to (7.335) as compared to BAP treatments. The proliferated shoots were subjected to full strength MS media supplemented with $0.75 \mathrm{mgl}^{-1}$ IAA give the optimal ratio of rooting. Survived rooted plantlets were acclimatized gradually and successfully transferred under greenhouse conditions for hardening.
\end{abstract}

Keywords- Strawberry, shoot multiplication, Micropropagation, TDZ.

\section{INTRODUCTION}

Strawberry (Fragaria ananassa) is dicotyledonous, perennial, stoloniferous herb and popular fruit which belongs to family Rosaceae grown in most arable regions of the world. Strawberry was one of the first fruit plants commercially cultivated in many counties in the world on a large scale. Is a major soft fruit around the world (Biswas et al., 2007). Strawberry has been traditionally the popular delicious fruit for its flavour, taste, fresh use, freezing and processing industry the fruits are rich of vitamin $\mathrm{C}, \mathrm{B} 1, \mathrm{~B} 2$, protein, calcium, potassium, copper and iron, most of the nutritious elements essential for human being. Strawberries are good sources of natural antioxidants, it contains relatively high qualities of ellagic acid, which is thought to be an anti-carcinogeni (Moradi et al., 2011). Strawberry is one of the few fruit crops that can be grown for production of its delicious fruit that www.ijeab.com generally arrives in the market at a time when no other fruits are available. It adapts very well in areas where there is provision for irrigation. It has also a tremendous scope for growing near the town and the canning units where the fruit can be utilized immediately after harvest. It can be successfully grown both under subtropical and temperate climatic conditions (Taji et al., 2002). They are important in transformation genes and genetic engineering that genetic engineering are an alternative efficient strategy to implement strawberry improvement ( Moradi et al.,2011)

Prior to micropropagaton, strawberry clones were propagated by runners. This method is relatively slow as it is limited to a finite number of plants produced on the runners and depended on season and does not guarantees virus elimination and mass production. Commercial production of Strawberry relies heavily on a continuous production of disease free clones throughout the year. Tissue culture has been effectively used in this regard as ensure the availability of the virus free clones as and when required ( Mohmood et al., 1994). In addition in vitro techniques are important tools for modern plant improvement programs to induce a large number of plants from a single individual one in a relatively short span of time and space, less than traditional runner plant (Taji et al., 2002). In view of the potential commercial value, it is highly desirable to develop methods of rapid, efficient and large scale multiplication of Strawberry through tissue culture. The most important technique of micropropagation were reported by various researchers using cultures of apical meristems excised from runners and nodal segments to regenerate multiple shoots without any intervening callus phase (Mohmood et al.,1994; Sakila et al., 2007; Litwinczuk et al., 2009; Moradi et al., 2011; Bhat et al., 2012; Ashrafuzzaman et al., 2013).

This is the first time to report on in vitro propagation of Strawberry in Kurdistan Region of Iraq. In the present study a simple protocol has been developed to propagate strawberry through tissue culture method by study the effect of plant growth regulators such as BAP(6-Benzyl amino purine), TDZ (Thidiazuron), Kinetin and 
$\mathrm{GA}_{3}$ (Gibberellic acid) in various combination in clonal multiplication in order to ensure abundant supply of this plant material for commercial cultivation as well as the shoot regeneration system can be used to develop transgenic plants following genetic transformation of plant cells.

\section{MATERIALS AND METHODS}

This investigation carried out in Plant Tissue Culture laboratory, Scientific Research Center at the University of Duhok, Iraq during the period from September, 2013 to May, 2014. Plant materials represented by runner tips were collected from the greenhouse of Malta Horticultural Nurseries, General Directory of Agriculture in Duhok Governorate in September, 2013. Runner tips were surface sterilized by $3.75 \%$ commercial bleach (sodium hypochlorite) for 15 minutes under gentle vacuum. Then, MS basal medium (Murashige and Skoog, 1962) supplemented with $0.4 \mathrm{mgl}^{-1}$ Thiamine $\mathrm{HCl}, 0.5 \mathrm{mgl}^{-1}$ BAP, $30 \mathrm{gl}^{-1}$ sucrose, $0.7 \% \mathrm{w} / \mathrm{v}$ agar and $100 \mathrm{mgl}^{-1}$ Inositol was used for the initiation stage. The $\mathrm{pH}$ of the medium was adjusted to $5.7 \pm 0.1$ using $0.1 \mathrm{~N} \mathrm{HCl}$ and/or $0.1 \mathrm{~N} \mathrm{NaOH}$ prior autoclaving at $121^{\circ} \mathrm{C}$ temperature and $1.04 \mathrm{~kg} / \mathrm{cm}^{2}$ pressure for $20 \mathrm{~min}$. three explants were inoculated per culture vessel. All aseptic cultures were maintained at $16 \mathrm{~h}$ photoperiod at $25 \pm 2{ }^{\circ} \mathrm{C}$ temperature.

For shoot multiplication stage, TDZ and BAP combined with $0.25 \mathrm{mgl}^{-1}$ from GA3, Kinetin or IBA at different concentrations $\left(0.0,0.5,1.0,1.5\right.$ and $\left.2.0 \mathrm{mgl}^{-1}\right)$ were tested to promote shoots multiplication from the successfully established explants. At rooting stage, IAA and IBA were used at different concentrations $(0.0,0.25$, $0.5,0.75$ and $1.0 \mathrm{mgl}^{-1}$ ) to test their ability to induce rooting shoots. Observations for both multiplication and rooting stages were recorded after 6 weeks of culture period. The experiment was designed as complete randomized design (CRD). The comparison between means was carried out according to Duncan's multiple range test $(\mathrm{P} \leq 0.05)$ using a computerized program of SAS (SAS, 2001).

Finally, for acclimatization stage, a quite number of successfully rooted plantlets were removed from culture vessels after washing their roots with distilled water and immersing them in Benlate fungicide $(0.1 \%$ for $10 \mathrm{~min}$.). Then they were transferred to pots containing a steam sterilized soil mix (peatmoss+ loam+ Styrofoam 1:1:0.5, $\mathrm{v}: \mathrm{v}: \mathrm{v})$ under tightly controlled atmosphere of the greenhouse.

\section{RESULTS AND DISCUSSION}

Following 2 weeks of incubation, the explants developed into a shoot, measuring $2-3 \mathrm{~cm}$. tall with several leaves (Figure 1, A).

\section{Effects of cytokinins on shoot multiplication}

Following six weeks of incubation of strawberry, new shoots were formed from shoot tips on cytokinin containing medium. The effect of BAP on shoot proliferation is shown in Table (1). The highest shoots number was attained at this $2.0 \mathrm{mgl}^{-1} \mathrm{BAP}$ concentration and was significantly higher than other treatments, except $0.5 \mathrm{mg} / \mathrm{l}$ one. Although the number of shoots was reached its highest level at the $2.0 \mathrm{mgl}^{-1}$ treatment, (3.165 shoots / explants) were developed, the next highest number of shoots was attained at the $0.5 \mathrm{mgl}^{-1}$ (3.00 shoots /explant). The difference between these two concentrations was not significant. On the other hand, inclusion of $1.0 \mathrm{mgl}^{-1}$ of BAP in the culture medium reduced the number of shoots, and only 2.083 shoots were developed. Similarly another reduction was achieved by reducing the BAP concentration to $1.5 \mathrm{mgl}^{-1}$, though this reduction was significant (Table, 1). The least shoot number was obtained in a medium devoid of BAP and was significantly different from all other treatments.

Table.1: Effect of BA alone and combined with other cytokinins or auxin on shoots multiplication in strawberry

\begin{tabular}{cccc}
\multicolumn{4}{c}{ after six weeks. } \\
\hline $\begin{array}{c}\text { BAP } \\
\text { Concentration } \\
\text { s }\left(\mathbf{m g l}^{-1}\right)\end{array}$ & $\begin{array}{c}\text { Numbe } \\
\text { r of } \\
\text { shoots/ } \\
\text { explant }\end{array}$ & $\begin{array}{c}\text { Mean } \\
\text { lengt } \\
\text { h of } \\
\text { shoot } \\
\text { s (cm) }\end{array}$ & $\begin{array}{c}\text { Numbe } \\
\text { r of } \\
\text { leaves/ } \\
\text { explant }\end{array}$ \\
\hline $\mathbf{0 . 0}$ & $1.458 \mathrm{~d}$ & $\begin{array}{c}0.815 \\
\text { a }\end{array}$ & $8.543 \mathrm{c}$ \\
$\mathbf{0 . 5}$ & $3.000 \mathrm{a}$ & 0.493 & $27.583 \mathrm{a}$ \\
& & $\mathrm{b}$ & \\
$\mathbf{1 . 0}$ & $2.083 \mathrm{c}$ & 0.450 & 16.085 \\
& & $\mathrm{~b}$ & $\mathrm{~b}$ \\
$\mathbf{1 . 5}$ & $2.665 \mathrm{~b}$ & 0.388 & 18.418 \\
& & $\mathrm{c}$ & $\mathrm{b}$ \\
$\mathbf{2 . 0}$ & $3.165 \mathrm{a}$ & 0.568 & 16.333 \\
& & $\mathrm{~b}$ & $\mathrm{~b}$
\end{tabular}

$\begin{array}{cccc}\begin{array}{c}\mathbf{B A}+\mathbf{G A} \mathbf{3} \\ (\mathbf{m g} / \mathbf{l})\end{array} & & & \\ \mathbf{0 . 5}+\mathbf{0 . 0} & 2.500 \mathrm{c} & 0.545 & 12.335 \mathrm{a} \\ & & \mathrm{a} & \\ \mathbf{0 . 5 + 0 . 2 5} & 3.083 \mathrm{~b} & 0.393 & 11.250 \mathrm{a} \\ & & \mathrm{b} & \\ \mathbf{1 . 0 + 0 . 2 5} & 3.083 \mathrm{~b} & 0.513 & 8.833 \mathrm{~b} \\ & & \mathrm{a} & \\ \mathbf{1 . 5 + 0 . 2 5} & 2.463 \mathrm{c} & 0.480 & 8.375 \mathrm{~b}\end{array}$




\begin{tabular}{|c|c|c|c|}
\hline $2.0+0.25$ & $4.000 \mathrm{a}$ & $\begin{array}{c}\mathrm{b} \\
0.553 \\
\mathrm{a}\end{array}$ & $10.043 \mathrm{a}$ \\
\hline \multicolumn{4}{|c|}{$\begin{array}{c}\text { BA+ Kinetin } \\
(\mathrm{mg} / \mathrm{l})\end{array}$} \\
\hline $0.5+0.0$ & $2.083 \mathrm{c}$ & $\begin{array}{c}0.503 \\
b\end{array}$ & $14.585 \mathrm{a}$ \\
\hline $0.5+0.25$ & $2.668 \mathrm{c}$ & $\begin{array}{c}0.435 \\
\mathrm{c}\end{array}$ & $12.833 \mathrm{a}$ \\
\hline $1.0+0.25$ & $3.168 \mathrm{~b}$ & $\begin{array}{c}0.555 \\
b\end{array}$ & $12.835 \mathrm{a}$ \\
\hline $1.5+0.25$ & $4.033 \mathrm{a}$ & $\begin{array}{c}0.743 \\
\mathrm{a}\end{array}$ & $13.000 \mathrm{a}$ \\
\hline $2.0+0.25$ & $4.000 \mathrm{a}$ & $\begin{array}{c}0.383 \\
\mathrm{~d}\end{array}$ & $12.920 \mathrm{a}$ \\
\hline \multicolumn{4}{|l|}{$\begin{array}{c}\mathbf{B A}+\mathbf{I B A} \\
(\mathrm{mg} / \mathrm{l})\end{array}$} \\
\hline $0.5+0.0$ & $4.000 \mathrm{c}$ & $\begin{array}{c}0.525 \\
b\end{array}$ & $\begin{array}{c}14.250 \\
b\end{array}$ \\
\hline $0.5+0.25$ & $2.200 \mathrm{~d}$ & $\begin{array}{c}0.433 \\
\mathrm{c}\end{array}$ & $9.000 \mathrm{c}$ \\
\hline $1.0+0.25$ & $3.967 \mathrm{c}$ & $\begin{array}{c}0.567 \\
b\end{array}$ & $\begin{array}{c}13.667 \\
b\end{array}$ \\
\hline $1.5+0.25$ & $5.500 \mathrm{~b}$ & $\begin{array}{c}0.623 \\
\mathrm{a}\end{array}$ & $17.775 \mathrm{a}$ \\
\hline $2.0+0.25$ & $6.375 \mathrm{a}$ & $\begin{array}{c}0.675 \\
\mathrm{a}\end{array}$ & $19.900 \mathrm{a}$ \\
\hline
\end{tabular}

Different letters within columns represent significant differences according to Duncan's multiple range test at $5 \%$ level.

The effect of BAP on shoot length is illustrated in Table (1). In general, the length of the shoot was reduced with different concentrations of BAP. The length of shoot averaged $(0.815 \mathrm{~cm})$ in the control treatment was significantly higher than shoots developed under different BAP concentrations. However, non significant reduction was observed between BAP treatments unless $1.5 \mathrm{mgl}^{-1}$ BAP level which recorded the least length of shoots $(0.388 \mathrm{~cm})$.

The highest number of leaves per explant was recorded for the $(0.5 \mathrm{mg} / \mathrm{l} \mathrm{BAP})$ treatment (27.583), which was significantly reduced to only 8.543 leaves/ explant in the control treatment. Our results indicated that medium contained $2.0 \mathrm{mg} / \mathrm{l} \mathrm{BA}$ alone proved to be the best for shoot formation, shoot number and number of buds. The results are in agreement with those of Emarah (2008); Ashrafuzzaman et al. 2013 who reported that BA alone at $(1.0$ and $0.5 \mathrm{mg} / \mathrm{l})$ significantly showed the highest record of shoot number/explants. While Mahmood et al 1994 reported that the low concentration from BA $(0.5 \mathrm{mg} / \mathrm{l})$ produced better results. The reasons behind the positive role of BA on multiplication stage might be due to cytokinins great role in releasing lateral buds by promoting the formation of xylem tissues of buds which will facilitate the transformation of water and nutrients leading to lateral bud growth as well as, the important role of cytokinins in increasing the synthesis of RNA, proteins and enzymes inside the cell which enhance bud growth as well (Mohammed and Al-Younis,1991).

Effect of the combination between different concentrations from BAP with $0.25 \mathrm{mgl}^{-1} \mathrm{GA}_{3}$ on micropropagation of strawberry are given in Table (1). Adding $2.0 \mathrm{mg} / \mathrm{l}$ BAP with $0.25 \mathrm{mg} / \mathrm{l} \mathrm{GA}_{3}$ gave significantly highest number of branches per explant (4.00) and gave the highest mean length of branches $(0.553 \mathrm{~cm})$ as compared to the control and other treatments, while the highest number of leaves per explant (12.335) was recorded in the control treatment which was significantly reduced to only 8.375 leaves/ explant in the medium supplemented with $1.5 \mathrm{mgl}^{-1}$ BAP. Similar results have already been reported in strawberry by Sakila et al. 2007 ; Litwinczuk et al. 2009 ; Bhat et al. 2012 these authors describe the influence of gibberellic acid on the formation of adventitious shoots when combination with BA . Fouad et al. (1991) recorded that gibberellins enhanced juvenile characteristics such as increased plant runner and delayed flowering, among others treatments due to the role of gibberellic acid in cell division and elongation.

Table (1) shows the effect of different BAP concentrations combination with $0.25 \mathrm{mg} / \mathrm{l}$ Kinetin on shoot proliferation of strawberry plant. The addition of BAP was significantly affective in increasing the number of shoots per explant as compared to the control. The highest number of shoots (4.033) and high shoot length $(0.743 \mathrm{~cm})$ was recorded while adding $1.5 \mathrm{mgl}^{-1}$ of BAP + $0.25 \mathrm{mgl}^{-1}$ Kinetin, whereas the lowest number was found in control treatment (2.083). On the other hand, the addition of $2.0 \mathrm{mgl}^{-1}$ BAP and 0.5 kinetin reduced significantly the mean length of shoots when compared to the control treatment. This might be due to the further competition on the nutrient medium between higher numbers of branches as a result of the addition of BAP. The results are in agreement with those of Sakila $e t$ al. 2007; Moradi et al. 2011; Bhat et al. 2012 whose found that the highest response of shoot multiplication was obtained in MS medium supplemented with BA and kinetin. Weifeng et al. 2004 revealed that Kin used with BA for adventitious bud induction gave better results than Kin alone but, Waithaka et al. 1980 revealed that axillary dormancy was released by including a large level $(50 \mu \mathrm{M})$ of Kin in the culture medium. The results can be explained on the basis that different plants and even 
different organs of the same plant are characterized not only by their unique intrinsic biochemical make-up but also by the sensitivity of the endogenously supplied chemical stimuli.(Youssief 2009)

The effect of different concentration of BAP combination with $0.25 \mathrm{mgl}^{-1} \quad$ IBA in strawberry plant shoots multiplication is shown in Table (1). Adding $2.0 \mathrm{mgl}^{-1}$ BAP combined with $0.25 \mathrm{mgl}^{-1}$ IBA gave highest number of branches per explant (6.375), highest average shoots length $(0.675 \mathrm{~cm})$ and highest number of leaves/explants (19.900) significantly when compared to the control treatments, while the lowest number of branches per explant (2.200) was recorded in the medium supplemented with $0.5 \mathrm{mgl}^{-1} \mathrm{BAP}+0.25 \mathrm{mgl}^{-1}$ IBA as well as the lowest mean shoot length $(0.433 \mathrm{~cm})$ and leaves number (9.0 leaves/explants) in the same treatment, significantly from other treatments.

In the present study, the use of $2.0 \mathrm{mgl}^{-1} \mathrm{BA}$ and 0.25 $\mathrm{mg} / \mathrm{l}$ IBA proved to be the best for shoot formation of strawberry (6.375 shoots per explants). These results are resemblance with those of Youssief (2009) who found that using $0.5 \mathrm{mgl}^{-1} \mathrm{BAP}$ and $0.5 \mathrm{mgl}^{-1}$ IBA will increase shoot proliferation of strawberry and Singh and Pandey 2004 reported that using half strength MS medium supplemented with $\mathrm{mgl}^{-1} \mathrm{BA}$ and $1 \mathrm{mgl}^{-1}$ IBA produced the highest number of shoots (13 per explant) and the combination IBA with BA will increase the branching of the plant.

The number of shoots per explant was highly influenced by the addition of TDZ to the nutrient medium Table (2). The highest number of shoots (7.335) was achieved from the addition of $1.5 \mathrm{mgl}^{-1} \mathrm{TDZ}$ (Fig. 1,B). The least shoot number (1.0) was obtained in a medium free of TDZ and was significantly different from all other treatment.

Table .2: Effect of TDZ on shoots multiplication in strawberry after six weeks.

\begin{tabular}{|c|c|c|c|}
\hline $\begin{array}{c}\text { TDZ } \\
\text { Concentration } \\
\mathrm{s}\left(\mathrm{mgl}^{-1}\right)\end{array}$ & $\begin{array}{c}\text { Numbe } \\
\text { r of } \\
\text { shoots/ } \\
\text { explant }\end{array}$ & $\begin{array}{c}\text { Mean } \\
\text { lengt } \\
h \text { of } \\
\text { shoot } \\
\text { s }(\mathrm{cm})\end{array}$ & $\begin{array}{c}\text { Numbe } \\
\text { r of } \\
\text { leaves/ } \\
\text { explant }\end{array}$ \\
\hline 0.0 & $1.000 \mathrm{~d}$ & 1.128 & $7.043 \mathrm{~b}$ \\
\hline & & $\mathrm{a}$ & \\
\hline 0.5 & $5.750 \mathrm{~b}$ & $\begin{array}{r}0.483 \\
b\end{array}$ & $8.083 \mathrm{a}$ \\
\hline 1.0 & $5.668 \mathrm{~b}$ & $\begin{array}{r}0.310 \\
b\end{array}$ & $6.918 \mathrm{c}$ \\
\hline 1.5 & $7.335 \mathrm{a}$ & $\begin{array}{r}0.283 \\
b\end{array}$ & $8.085 \mathrm{a}$ \\
\hline 2.0 & $4.553 \mathrm{c}$ & $\begin{array}{r}0.253 \\
b\end{array}$ & $5.443 \mathrm{~d}$ \\
\hline
\end{tabular}

Different letters within columns represent significant differences according to Duncan's multiple range test at $5 \%$ level.

At the same time, results of table (2) clarified the effect of TDZ on shoot length. In general, the length of the shoots was reduced by increasing TDZ concentration. The mean of shoots length $(1.128 \mathrm{~cm})$ in the control treatment was significantly higher than the shoots developed in the media contained different concentrations from TDZ, which was not significant among those treatments. The highest number of leaves per explant was recorded in the $1.5 \mathrm{mgl}^{-1}$ TDZ (8.085) leaves/explants, which was significantly reduced to only 5.443 leaves/ explant when $2.0 \mathrm{mgl}^{-1} \mathrm{TDZ}$ was added to the nutrient medium. The positive role of TDZ in strawberry plant tissue culture was reported by using TDZ alone or combined with other cytokinins or auxin, the shoot proliferation percentage was reached its maximum value in MS medium supplemented with $1.0 \mathrm{mgl}^{-1} \mathrm{TDZ}$ (Diengagan and Murthy 2014) while Haddadi and Abd Aziz (2010) reported that MS medium supplemented with $2 \mu \mathrm{M}$ TDZ and $4 \mu \mathrm{M}$ BAP gave the optimal shoots multiplication from shoot tips, high concentration of TDZ combination with IBA gave the best results for shoot multiplication ( Murti et al. 2012). To interpreted that, diverse of underlying mechanisms were revealed to show how morphogenic events were induced by application of TDZ. Other reports showed that TDZ may modify endogenous plant growth regulators either directly or indirectly to induce necessary reactions in cell/tissue, affecting its division/regeneration. Other possibilities include modification in cell membrane, energy levels, nutrient absorption, transport and assimilation (Guo et al.2011).

\section{Effects of auxins on rooting}

The results revealed that the two tested auxins (IAA and IBA) stimulated root initiation in strawberry, however, the extension of rooting varied according to auxin type and its concentration. IAA as the most active growth regulators reveals that the highest rooting percentage $100 \%$ was recorded in the medium supplemented with 0.25 or $0.75 \mathrm{mgl}^{-1}$ IAA. On the other hand, the media supplemented with $0.75 \mathrm{mgl}^{-1}$ IBA gave the highest percentage $(100 \%)$ of rooting. Inclusion of IAA to the medium reduce the numbers of roots / explant when compared with the control treatment unless $1 \mathrm{mgl}^{-1}$ concentrations which was non significant increment (Table 3) where as the lower concentration $\left(0.5 \mathrm{mgl}^{-1}\right)$ cause a significant reduction or in roots number $(4.83$ roots / explant) Root length, on the other hand, reached its maximum value at the $0.75 \mathrm{mg} / \mathrm{l}$ IAA level $(4.393 \mathrm{~cm})$ 
which was differ significantly when compared to other treatments (Figure 1, C and D).

Table .3:Effect of IAA, IBA on strawberry rooting after six weeks.

\begin{tabular}{ccccc}
\hline Auxin & $\begin{array}{c}\text { Conc. } \\
\text { Mgl }^{\mathbf{1}}\end{array}$ & $\begin{array}{c}\text { Rooting } \\
\text { Percentage\% }\end{array}$ & $\begin{array}{c}\text { Number } \\
\text { of roots/ } \\
\text { explant }\end{array}$ & $\begin{array}{c}\text { Mean } \\
\text { length of } \\
\text { roots(cm) }\end{array}$ \\
\hline \multirow{4}{*}{ IAA } & 0.0 & $91.675 \mathrm{~b}$ & $6.790 \mathrm{a}$ & $3.905 \mathrm{a}$ \\
& 0.25 & $100 \mathrm{a}$ & $4.833 \mathrm{~b}$ & $3.100 \mathrm{~b}$ \\
& 0.50 & $91.675 \mathrm{~b}$ & $7.043 \mathrm{a}$ & $2.933 \mathrm{c}$ \\
& 0.75 & $100 \mathrm{a}$ & $6.265 \mathrm{a}$ & $4.393 \mathrm{a}$ \\
& 1.00 & $83.350 \mathrm{c}$ & $6.875 \mathrm{a}$ & $2.460 \mathrm{c}$ \\
& & & & \\
IBA & 0.0 & $91.675 \mathrm{~b}$ & $5.790 \mathrm{~b}$ & $3.525 \mathrm{a}$ \\
& 0.25 & $83.325 \mathrm{c}$ & $7.083 \mathrm{a}$ & $2.828 \mathrm{~b}$ \\
& 0.50 & $83.350 \mathrm{c}$ & $5.250 \mathrm{~b}$ & $3.725 \mathrm{a}$ \\
& 0.75 & $100.000 \mathrm{a}$ & $2.455 \mathrm{c}$ & $2.410 \mathrm{~b}$ \\
& 1.00 & $91.675 \mathrm{~b}$ & $8.208 \mathrm{a}$ & $2.968 \mathrm{~b}$ \\
\hline
\end{tabular}

Different letters within columns represent significant differences according to Duncan's multiple range test at $5 \%$ level.

On the other hand, IBA caused a significant increase in roots number when compared to the control treatment.
Table 3 also showed that the optimal concentration of IBA to induced rooting initiation is $1.00 \mathrm{mgl}^{-1}(8.208$ roots per each shoot), and there were significant differences when compared with control treatment. A comparable number of roots were also developed at 0.25 $\mathrm{mgl}^{-1}$ IBA level (7.083) roots although the non significant differences were observed between them. For root length, it was observed that an inverse relation was existed between IBA concentration and root length. Best root length was $(3.725 \mathrm{~cm})$ achieved at $0.50 \mathrm{mgl}^{-1}$ treatment, and significant differences were recorded among other treatment except the control.

The results showed that IAA is most suitable for root induction in strawberry plants and this results were not harmonious with those of Sakila et al. 2007 ; Moradi et al. 2011; Ashrafuzzaman 2013 whose observed the best root formation for strawberry in the medium contained IBA.

These results indicated that the positive role for auxin on an in vitro rhizogenesis in strawberry is due to its effects in improvement of the cell wall elasticity and stimulates cell elongation followed by adventitious root formation (Damiano et. al., 2007).

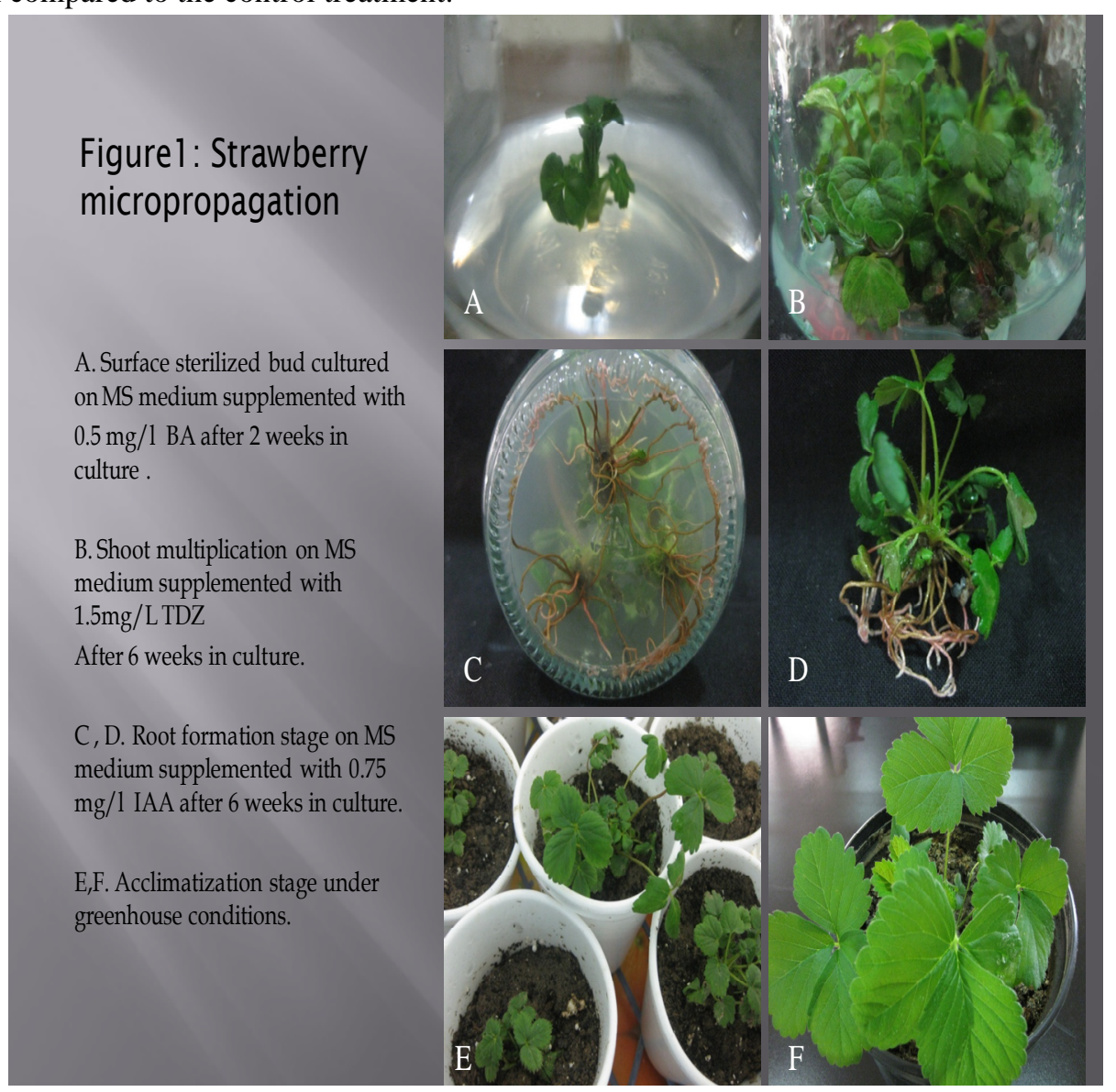




\section{REFERENCES}

[1] Ashrafuzzaman, M.; Faisal,S.M.; Yadav, D.; Khanam,D. and Raihan, F. (2013). Micropropagation of strawberry (Fragaria ananassa) through runner culture. Bangladesh J. Agril. Res. 38(3):467-472.

[2] Biswas, M.K.; Hossain, M.; Ahmed, M.B.; Roy, U.K.; Karim, R.; Razvy, M.A.; Salahin, M. and Islam, R. (2007). Multiple Shoots Regeneration of Strawberry under Various Colour Illuminations. American-Eurasian Journal of Scientific Research 2: 133-135.

[3] Bhat, R.P.; Devi, K.M.; Jayalaxmi, H.; Sophia, I. and Prajna, P.S.(2012). Effect of plant growth regulators on establishment and growth of strawberry (Fragaria x ananassa Duch.) var. chandler in vitro. Agriculture Science Research Journals, 2(12):623-632.

[4] Damiano, C., P. Arias, M.D. Starza, S. R. la and A. Frattarelli. (2007). Temporary immersion system for temperate fruit trees. Acta Hortic. 748:87-90.

[5] Diengngan, S. and Murthy, N.S. (2014). Influence of plant growth promoting substances in migropropagation of strawberry cv. Festival. The Bioscan 9(4): 1491-1493.

[6] Emarah., (2008). Factors affecting propagation of strawberry (Fragaria spp.) through tissue cultures. J. Product. \& Dev., 13 (1), 191-212.

[7] Fouad, M.; Swartz, H. J. and Buta, J. G.( 1991). The role of abscisic acid and plant growth regulators in tissue culture-induced rejuvenation of strawberry in vitro. Plant Cell Tiss. Org. Cult. 25(1): 75-84.

[8] Guo, B. ; Abbasi, B.H. ; Zeb, A.; Xu, L. L. and Wei, Y. H. (2011). Thidiazuron : amulti- dimensional plant growth regulator. African Journal of Biotechnology. 10(45): 8984- 9000.

[9] Haddadi, F. and Abd Aziz, M. (2010). Micropropagation of strawberry cv. Camarosa prolific shoot regeneration from in vitro shoot tips using thidiazuron with $\mathrm{N}_{6}$ benzylamino-purine. Hort Scence 45(3): 453-456.

[10]Litwinczuk, W.; Okototkiewicz, E. and Matyaszek, I. (2009). Development of in vitro shoot cultures of strawberry (Fragaria ananassa Duch.) ' Senga Sengana' and Elsanta' under the influence of high doses of gibberellic acid. Folia Horticulture Turae, 21(2): 43-52.

[11] Mahmood, S.; Rashid, A.; Quraishi, A.; Iqbal,N.; Arjumand,S. and Malik,M.N.(1994).Clonal propagation of Strawberry through tissue culture. Pakistan J. Agric. Res. 15(1):54-59.
[12] Mohammed, A.K. and M.A. Al-Younis, (1991) Fundamentals of Plant Physiology (3rd Part), College of Agriculture, Baghdad University, Iraq, (In Arabic).

[13] Moradi, K.; Otroshy, M. and Azimi, M.R. (2011). Micropropagation of strawberry by multiple shoots regeneration tissue culture. J. Agriculture Technology. 7(6): 1755-1763.

[14] Moradi, K.; Otroshy, M.; and Azimi, M.R. (2011). Micropropagation of strawberry by multiple shoots regeneration tissue cultures. Journal of Agricultural Technology. 7(6):1755-1763.

[15] Murashige, T. and F. Skoog. (1962). A revised medium for rapid growth and bioassays with tobacco tissue culture. Physiol. Plant. , 15: 473-497.

[16]Murti, R. H.; Debnath, S.C. and Yeoury, Y.R. (2012). Effect of high concentration of thidiazuron (TDZ) combined with $1 \mathrm{H}$-indole-3- butanoic acid (IBA) on Albion strawberry (Fragaria $\mathrm{x}$ ananassa) cultivar plantlets induction. African Journal of Biotechnology. 11(81): 14696-14702.

[17] Sakila, S.; Ahmed, M.B.; Roy, U.K. and Biswas, M.K.(2007). Micropropagation of Strawberry (Fragaria ananassa Duch.) a newly introduced crop in Bangladesh. American-Eurasian Journal of Scientific Research, 2(2):151-154.

[18]SAS. (2001). SAS/STAT Vser's Guide for personal Computers. Release 6.12 SAS Institute Inc. Cary, NC, USA.

[19] Singh, A. K. and S. N. Pandey., (2004). Genotypic variation among strawberry cultivars for shoot organogenesis. Acta Horticulturae. 662 : 277- 80.

[20] Taji A, Kumar PP, Lakshmanan P (2002). The field performance of strawberry nursery stock produced originally from runners or micro propagation. Strawberry Production 4: 56-58.

[21] Waithaka, K.; A. C. Hildebrandt and M. N. Dana., (1980). Hormonal control of strawberry axillary bud development in vitro. Journal of Am. Soc. Hortic. Sci., 105:428-430.

[22] Weifeng, Y.; J. Wanmei and Y. Shupin., (2004). Effect of plant growth regulators on adventitious shoot regeneration from strawberry (Fragaria ananassa) leaf discs. Plant Physiology Communications. 40 (4): 447-449.

[23] Youssief, E.Y. ,(2009). In vitro propagation of strawberry (Fragaria $\mathrm{x}$ annanasa Duch.) through organogenesis via runner tips. M.Sc. dissertation in Biology, University of Gaza, Faculty of Science, Palestine. 